\title{
Bounds Testing Approach to Find the Impact of Capital Inflow on Real Output Growth of Pakistan
}

\author{
Nazima Ellahi (Corresponding author) \\ Lecturer, Department of Economic, Foundation University Islamabad, Pakistan \\ Tel: 92-332-522-5675Ｅ-mail: nazimaellahi@yahoo.com
}

Hafiz Zahid Mahmood

Assistant Professor, Department of Management Sciences

COMSATS Institute of Information Technology, Lahore, Pakistan

Tel: 92-303-458-5985Ｅ-mail: hzmahmood@hotmail.com

Received: January 29, 2012

Accepted: February 14, $2012 \quad$ Published: April 1, 2012

doi:10.5539/ijef.v4n4p106

URL: http://dx.doi.org/10.5539/ijef.v4n4p106

\begin{abstract}
The dollar recipient countries of the world utilize the funds to augment their developmental activities, curtail balance of payment distortions, enhance the pace of economic growth, and alleviating poverty. Capital flows into these economies, in two forms, firstly foreign direct investment and secondly, in the form of foreign aid. However, the present study is, mainly, conducted to check the impact of Foreign aid (FA) and foreign direct investment (FDI) on real output growth of Pakistan. To test the empirical relationship, the study utilized annual time series data set over the period 1970 to 2010 . Econometric techniques include testing the stationarity of data by applying augmented Dicky Fuller (ADF) test and applying Autoregressive Distributed Lag (ARDL) method of estimation. Moreover, Short run and long run estimates were found. The findings suggested a robust and direct link between economic inflow of foreign capital and economic performance indicators. However, the magnitude of foreign aid impact was explored considerably low as compared to FDI. In the end, it is suggested that though impacts of capital inflows are positive but economies must rely upon the indigenous resources to promote development rather depending on external factors.
\end{abstract}

Keywords: Capital inflow, Bounds testing, Real output growth

\section{Introduction}

Developing countries of the world face the hazards of poverty and low level of living. To meet the challenge of sustained economic growth, they require financial resources. Against this background and rising macroeconomic imbalances among the developing world, investment needs to increase growth performance at high pace. A number of development programmes are launched by multilateral funding agencies (Note 1) to make better economic activities and achieve high growth rates in recipient countries (Ndambendia and Njoupouognigni, 2010). Consequently there is a shortfall of resources in the developing world which leads to resources inflow to meet deficiency of resources and fill two gaps, i.e. saving investment gap (Note 2) and import export gap (Ghulam, 2005). These funds flow either in foreign aid (Note 3) or foreign direct investment form, from rich nations to poor nations to trim down budget deficit, alleviating poverty, and help promoting the trade activities among the nations along with ensuring the overall macroeconomic stability (Khan, 2007). As a classical example, a number of aid recipient countries (Note 4) have extracted numerous benefits while going through their development stages, these countries experience relatively high growth rates after proper utilization of capital inflows (Mosley, 1987).

Foreign aid (Note 5) includes funds entering from surplus units i.e. developed and rich nations to deficit units i.e. Developing and poor countries of the world. Analysis of literature suggests that there are two contrasting arguments. First confirms a direct relationship between growth performance and official Developments Assistance(Note 6) Furthermore it is suggested that aid helps to maintain structural adjustment programs and macroeconomic stability. A World Bank Report asserts that international donor agencies has brought innovations in agricultural sector, enhanced investment activities, and helped millions of poor people all over the world to improve their lives. Another 
point of view regarding its impact is about the ineffectiveness of these resources for enhancing economic development and economic growth. The major reasons accredited to this inadequacy are mis-governance of government, corruption and ill utilization of resources in these countries. According to UNCTAD (2006) FDI is a source for employment generation, it catalyzes high productivity and trade volume, a channel of technological spillover, and an element to affect directly the long-term development activities for the countries placed in third world countries. Bloomstrom and Wang (1992) mentioned benefits of foreign direct investment including the technological spillover as the major one; the maximum benefits are through inflow in manufacturing sector and services sector.

With the introduction of reforms and shift to market oriented economy Pakistan has emerged among one of the leading nations with high growth rate in South Asian region (Iqbal et al, 2010). Pakistan faced scarcity of financial resources; the resource inflow in the form of foreign aid has been started with the independence in different forms (Note 7). During the era of 1960s and 1970s Pakistan has been one of the largest aids receiving country in south Asian region (Khan, 2007). With emergence of economic reforms, Pakistan introduced reforms to enhance and encourage foreign direct investment in the country during the decade of eighties and nineties. Since the goal of developing nations is capital accumulation and achieving high welfare and growth rates, so foreign direct investment can also be considered as a supplement for foreign aid in third world countries. Ericsson and Irandoust (2005) state that foreign direct investment is an additional source of financing and serves as a supplement to savings and foreign aid.

Figures 4 below highlights the trends of foreign aid and foreign direct investment over the period 1970 to 2010 . A world Development Report asserts that volume of funds available to developing countries in the form of FDI increased considerably during mid eighties to 2000 . It rose from 0.2 billion US dollars to approximately 60 billion US dollars in Pakistan over 1990 to 2009 (WDI Indicators 2009). A time period of eighties and nineties in Pakistan is characterized by adoption liberalization programs of trade and investment regime. Restrictions on capital inflow were removed to increase competition and encourage foreign investors. These policies increased greatly the share received in the form of FDI by Pakistan during last twenty years. So the high FDI to GDP ratio has been observed during the post liberalization period (Khan, 2007)

The present study is an addition to empirical literature for Pakistan as it takes the both forms of capital inflow as a determinant of output growth in Pakistan. The robust methodology of ARDL is employed to find the short run as well as long run estimates. The brief organization includes: following the introduction section, section II presents brief literature of previous studies conducted to find the link between capital inflow and economic growth indicators. Section III presents methods and materials. Results are given in section IV, while final section concludes the study.

\section{Review of Previous Studies}

A number of theoretical as well as empirical studies have been found in the literature to highlight the significance of capital inflow in developing countries. Provided here is the brief review of a few studies, providing arguments in favor or against the FDI and foreign aid for economic growth performance. The section provides the literature on foreign aid and foreign direct investment separately in two sections.

\subsection{Studies Related to Foreign Aid and Economic Growth Link}

One view point on foreign aid states that foreign assistance in the form of foreign aid supports growth and development in developing countries, Durbarry et al. (1998) tested the statement by using both, panel and cross sectional techniques and found that aid accelerates economic growth but its effectiveness varies over the time depending upon its volume, geographical location and classification of country on the basis of income level. It was suggested that these fruits are conditioned upon stable macroeconomic policy environment. On the same lines Easterly (2003) checked the relation by developing a theoretical framework and also confirmed the relation empirically by panel analysis. It also tested its effectiveness on growth performance and found a positive and robust link of economic growth and foreign assistance. A common finding possessed by both studies suggested that a lack of investment friendly environment discourages inflow of FDI and therefore, most of the economies depend on foreign aid.

Regarding the effectiveness of aid flow, Ghulam (2005) analyzed the same case and found this assistance effective for the growth performance of Pakistan over the 1960 to 2002. The study asserted that foreign aid helped to boost economic growth through its positive and supportive impact on all sectors of the economy. The study also added that good fiscal and monetary policy is an important determinant of its effectiveness on growth. Ekanayake et al. (2003) also checked the impact of official development assistance for the economic growth for a sample of 85 underdeveloped countries (Note 8) over the period 1980 to 2007. It applied panel data techniques and found mixed evidence on tested link between economic growth and assistance via development funding agencies, these results 
were country specific, according to which all countries get benefits different from other countries depending upon economic structure and special economic features.

African countries constitute a major block of developing countries, and represent an ample mark of aid recipient group, Malik (2008) applied co-integration analysis for a sample of six African countries and found that short run effects of investment, trade openness, foreign aid have been positive while the long run effects were found to be negative for foreign aid on economic performance. An empirical analysis conducted by Nyoni (1997) studied the impact of foreign aid on economic growth of Tanzania. Economic indicators included export performance, exchange rate, government expenses and economic growth. Co-integration methods for finding the long run link were used and short run link is evaluated through Error Correction Methods (ECM). Findings of the study suggested that government spending cause high value of exchange rate, while foreign aid inflows cause devaluation and depreciation of local currency. Major policy implications suggested that foreign assistance is required to be utilizing for the productive sector of economy. Furthermore it was suggested that liberalization and openness of economy causes a positive impact in long run.

Further literature on testing the impact of foreign aid and foreign direct investment jointly included Ndambendia (2010), who investigated the link between foreign direct investment, foreign aid and economic growth for a sample of 36 African counties. Using a data set for 1980 to 2007, this study applied dynamic fixed effect techniques and found a positive and robust link of both foreign direct investment and foreign aid for the growth of these countries. Policy implication suggested that countries are required to depend on internal factors for enhancing growth rather than relying on external sector. Similarly the joint impact of both capital forms has been tested by Bhandari et al. (2007) for the sample of European countries (Note 9). It used pooled data set with annual frequency of data set over a long range of time comprising of 1993 to 2002 and applied panel technique of fixed effects. Major findings include effectiveness of both forms of capital inflows for economic growth. It included that FDI inflow is an important determinant of economic sector performance while foreign aid did not play an important role to enhance growth for the sample of this country.

For Pakistan economy, during the decades of 60s and 70s there have been a significant inflow of aid, which reduced during late 1970s (Note 10). Over the time aid turned to be consisting of loans rather than grant or grant type loans. Share of aid to GDP dramatically increased due to entering the 'War against Terrorism'. There was about seven folds high aid available to Pakistan. The high aid received by Pakistan during different time periods could not be utilized for development purposes rather it remained within the hands of elites and politicians and there has also been debt problem due to conversion of aid to grant. According to Ishfaq (2004), Pakistan considered aid as a key determinant of financing, implementing and entertaining different socio-economic development programs. However, the accessible external aid has not always been utilized in formulation and implementation of effective programs, while a sensible use of external assistance has been instrumental in achieving accelerated development of many less developed countries of the world. Many nations have failed to use it optimally as a result such countries have accumulated significant amount of debt with not many benefits in terms of economic growth and living standard for the poor. The point of view is that foreign aid has adverse effect on the development of recipient countries. Khalidi (2008) selected a time period 1990 to 2005 and studied the impact of trends of foreign aid for economic development of Jordan. Statistical analysis revealed that capital inflow in the form of foreign aid has positive direct effect on economic growth.

\subsection{Studies on Relationship between Foreign Direct Investment and Economic Growth}

To attract Foreign Direct Investment (FDI) recipient countries introduce market reforms and policies which are more investment friendly and encourage competition Chenery and Strout (1966). Miankhel etal. (2009) regressed the foreign direct investment and exports on economic growth for South Asian and emerging economies (Note 11) and suggested a causal link exists between exports and economic growth while in long run FDI is a driving force to enhance economic growth in Pakistan and India. Multivariate VAR and Error correction Models (VECM), techniques found mixed but country specific outcomes. There is an increasing consensus among economists that technological spillover can enhance economic growth by the element foreign direct investment. An empirical analysis by Khan (2007) tested the new direction of relationship through introducing the financial sector development performance for Pakistan. A time series data ranging over 1972 to 2005 with annual frequency was used it applied Autoregressive Distributed Lag cointegration and found that benefits to economic growth can be achieved through improvement of financial sector performance in the host countries as it attract more funds from developed countries for investment.

Panel data techniques have also been tested by Zhang (2006) to test for growth driven by FDI for the China. This study illustrated the possible channels through which FDI causes positive as well as negative impacts on economic growth. It utilized provincial data set of inland and coastal areas over the period 1992-2004 and found that foreign 
direct investment has positive impacts on economic growth and these effects have been found more robust for the coastal areas of China. Causal link between foreign direct investment and economic growth is also important in literature. A study conducted by Iqbal et al. (2010) tried to find the causal link between openness to trade, foreign direct investment and economic growth for Pakistan. it utilized quarterly data set over the period 1998-2009 and applied Vector Auto Regressive (VAR) model to test the existence of long run relationship. While direction of causality is found by multivariate VECM. Bidirectional causality between trade sector growth and economic FDI is detected, while a positive and robust link has been found between FDI and trade promotion in long run.

Small open economies depend on other sources for financing, studies for small economy of Ireland has been conducted by Kim and Bang (2008). The study tried to find the link between FDI and economic growth, by utilizing an annual time series data set over the period 1975-2006. Auto Regressive Distributed Lag (ARDL) method found that there exists a significant positive long run relationship in short run as well as long run. To find the direction of causality Granger causality test found that results indicated that foreign direct investment leads economic growth. Foreign direct investment helps creating job opportunities in host countries and supplements domestic financial resources, enhances competition along with technological spill over. In the same context another effort has been put forward by Athukorala (2003) to check the effects of FDI on economic growth indicators of Sri Lanka. Annual time series data set over the period 1959-2002 has been used with applying econometric techniques of cointegration and ECM. The findings have been little ambiguous because net effect of FDI on economic growth was not very much strong due to corruption, bad law and order situation and poor governance structure.

For Western European and US economy Katarina and John (2004) explored the dimensions of foreign direct investment and their impact for economic growth. Bayesian analysis is applied to find the nature of relationship between FDI and economic growth. This study does not support any significant relationship between these variables for Transition economies.

\section{Methods and Materials}

The data set utilized for this study consists of annual time series over 1970 to 2010. Data is collected through International Financial Statistics (IFS), various issues of Pakistan Economic Survey, and World Development Indicators. Major indicators include labor force, capital stock, real GDP per capita, foreign direct investment as a share of GDP, and foreign aid as a share of GDP. Auto Regressive Distributed Lag (ARDL) methodology is used for estimation on using Eviews software package (note 12). The methodology used here possesses certain characteristic features including: firstly, It is most suitable method of cointegration for small sample data set as also mentioned by Ghatak and Siddiki (2001), and secondly, it does not require all variables to be integrated of same orders, variables with different orders of integration can be used for estimation or this methodology does not depend upon the unit root properties of dataset. This ARDL approach consists of two steps, in first step F-test is applied to find out the existence of long run relationship and step two estimates short run and long run estimates of the model, short run elasticities of the model are found by ECM representation of the model. ECM version is used to calculate the speed of adjustment to equilibrium moreover, here stability test of CUSUM and CUSMSQ are also applied. The error correction form of ARDL model to be estimated can be written in this form:

$$
\begin{aligned}
& \Delta \ln (R Y)=\alpha_{0}+\sum_{i=1}^{p} \phi_{i} \Delta \ln (R Y)_{t-i}+\sum_{i=0}^{p} \theta_{i} \Delta \ln (F D I)_{t-i}+\sum_{i=0}^{p} \lambda_{i} \Delta(F A)_{t-i}+\sum_{i=0}^{p} \gamma_{i} \Delta \ln (S I)_{t-i} \\
& +\sum_{i=0}^{p} \psi_{i} \Delta \ln (L A B)_{t-i}+v_{1} \ln (R Y)_{t-1}+v_{2} \ln (F D I)_{t-1}+v_{3} \ln (F A)_{t-1}+v_{4} \ln (S I)_{t-1}+v_{5} \ln (L A B)_{t-1}+v_{t}
\end{aligned}
$$

Where $\ln (R Y), \ln (F D I), \ln (F A), \ln (S I)$ and $\ln (L A B)$ are natural logs of real GDP, foreign direct investment, official development assistance, share of investment and labor force respectively. $p$ is optimal lag length and $\Delta$ is first difference operator, $\phi_{i}, \theta_{i}, \lambda_{i}, \gamma_{i}$, and $\psi_{i}$ are representing the short run effects of variables while $v_{1}, v_{2}, v_{3}$, $v_{4}$, and $v_{5}$ are to represent the long run elasticities.

\section{Empirical Results}

First step of estimation involves testing the time series properties of data (i.e. to find the order of integration) using Augmented Dicky Fuller (ADF)(Note 13) test. Second stage tests the existence of long run relationship using ARDL (Note 14) bound testing approach of cointegration proposed by Pesaran et al. (2001) Table 1, below reports the results of unit root test. These results show that real GDP, Share of FDI in GDP, Share of Foreign aid (FA) in GDP and Share of investment (a proxy to capture the effects of capital stock) in GDP are non stationary at their level and become stationary at first difference, while labor force (LAB) is non stationary at level. Unit root test provides 
mixed results i.e. order of integration are different. Therefore, there is a justification for the application of ARDL cointegration. Cointegration test results are reported below in Table 2.

Cointegration test results are reported in Table 2 below. Here calculated F-stat is greater than critical value, so we reject null hypothesis, concluding that there is an evidence of long run relationship. After establishing the long run relationship, next step is finding short run as well as long run estimates of the model. Table 3 below is showing short run and long run estimates calculated through Eviews software packages. These results state that in short run foreign direct investment has negative effect, while this effect is positive for foreign aid. The signs possessed by coefficients of labor force and share of investment in GDP are negative and positive respectively which supported theoretically. Long run estimates are calculated using short run coefficients and long run relationship is given below in equation 4.1. Long run equation states a significant positive effect of foreign direct investment, as the inflow of FDI to developing nations provides a supplement for domestic credit and introduces new technology along with providing better employment opportunities to host country. On the contrary a negative and significant effect of foreign aid in long run is observed, because of poor disbursement of aid received, inefficient policies regarding inflation, trade openness, large and inefficient governance body of government (Whitaker, 2006). Labor force and investment have negative impacts, Pakistan is a developing country and characterized by surplus labor. Further increase in labor force causes negative impact on economic growth. Negative impact of capital stock is because of inefficient policies pursued by government. Short run diagnostic tests are applied and results are reported in Table 3. Here a reasonable value of $\mathrm{R}_{\text {adj }}^{2}$ is indicating that there is $67 \%$ variation in dependent variables explained by independent variables in the model. There is also no incidence of autocorrelation and F-stat shows that overall model is best fitted. Coefficient of LRY (-1) is negative and significant, and it is adjustment coefficient indicating $20 \%$ adjustment in long run equilibrium, if disturbed. Its negative sign also confirms cointegration among the variables. Furthermore the stability of parameters has been tested by Cumulative sum (CUSUM) and cumulative sum of square (CUSMSQ) test. The graphs for both are given in Figure 2 below. These graphs show that our estimated parameters are stable. The $\log$ run elasticities are found by normalization and taking the value of RY(-1) as one. Long run equation estimated is given here in equation (4.1).

$$
\mathrm{LY}=0.45+0.75(\mathrm{FDI}) * * *-0.35(\mathrm{FA}) * * *-2.84(\mathrm{LAB})-0.03(\mathrm{LSI})^{*}
$$

\section{Conclusion and Recommendations}

In this empirical analysis we tried to examine the relationship between foreign direct investment, foreign aid and economic growth for Pakistan specifically it is aimed to test the effectiveness of external factors. This study considered labor force and capital stock as internal factors while using neoclassical growth theory it incorporates external factors like official development assistance and foreign direct investment, to explain the changes in real GDP. An annual time series data set over the period 1970 to 2010 is utilized with application of recent econometric methodology of Auto Regressive Distributed Lag (ARDL). Recent data techniques are applied to diagnose and check the time series properties of data; later estimation was carried out where Short run and long run elasticities are estimated.

Our results state that capital stock and foreign direct investment are important factors which affect significantly and positively in short run as well as long run, while foreign aid seems to be an unimportant factor for economic growth in long run because of its inefficient utilization in developing countries, poor financial services along with infrastructure, the problem of bad governance and fiscal policy. Labor force had negative impact in short run as well as long run which can be attributed to the reason that Pakistan is a developing nation and it is endowed with surplus labor. More increase in labor force further causes negative impact on economic growth. Capital stock has positive effect in short run but these effects are negative in long run which is not supported theoretically, it is because of inefficient policies pursued by government. Our findings are consistent with the findings of Bhandari et al. (2007), Ndambendia (2010) and partially in line with Uphadhya and Kamal (2003).

A bidirectional Causality runs between foreign aid and economic growth. Official development assistance is causing foreign direct investment as well. So on the basis of overall results it is recommended that internal factors must be tried to achieve stability and developing countries should improve their infrastructure, fiscal situation and investment at domestic level to approach high economic growth index. Furthermore it is required that economies concentrate on their own resources rather than relying on financing from external sources to attain self-sufficiency and economic growth.

\section{References}

Authokorala, P. W. (2003). The Impact of Foreign Direct Investment for Economic Growth: a case study of Sri Lanka. International Conference for Sri Lanka Studies. 
Bandow, D. (1985). The U.S. Role in Promoting Third World Development. The Heritage Foundation, Washington, W.P No, 6.

Burnside, C., \& Dollar, D. (2000). Aid, Policies, and Growth, American Economic Review, American Economic Association, 90(4), 847-868.

Bhandari, R., Dhakal, D., Pradhan, G., \& Upadhyaya, K. (2007). Foreign Aid, FDI and Economic Growth in East Euorpean Counteries. Economic Bulletin, 06 (13), 1-9.

Chenery, H. B., \& Strout, A. M. (1966). Foreign Assistance and Economic Development. American Economic Review, 04(01), 679-733.

Din, G. M. (2005). Impact of Foreign Aid on Economic Deveopment of Pakistan. Munich Personal REPEC Archive, paper No. $1211,1-20$.

Easterlay, W. (2003). Can foreignAid buy Economic Growth. Journal of Economic Perspective, Vol 13 (02), pages 23-48. http://dx.doi.org/10.1257/089533003769204344

Ericsson J., \& Irandoust M. (2005). Foreign aid, domestic savings, and growth in LDCs: an application of likelihood-based panel cointegration. Economic modeling, 22, 616-627.

R.D. (1998). New Evidence on the Impact of Foreign Aid on Economic Growth. CREDIT Research Papaers, Centre for Researchin Economic Developmentand International Trade, University of Nottingham No.98/8.

Ghatak, S., \& Siddiki, J. (2001). The use of ARDL approach in estimating virtual exchange rates in India, Journal of Applied Statistics, vol.11, pages, 573-583.

Iqbal, M. S., Sheikh, F. M., \& Shar, A. H. (2010). Causality Relationship between Foreign Direct Investment, Trade and Economic Growth in Pakistan. Asian Social Science Journal, 06.

Ishfaq, M. (2004). Aid effectiveness, Debt Capacity and Debt Management in the Economy of Pakistan, A dissertation submitted for Ph.D. Degree to Quaid-e-Azam University, Islamabad.

Katerina, L., \& John, P. (2004). Foreign Direct Investment and Economic Growth in Transition Econnomies. South Eastern Euorpe Journal of Economics, 97-110.

Khaldi, D. M. (2008). Effect of Foreign Aid on Economic Development in Jordan. Journal of Social Sciences, (1), 14-21.

Khan, M. A. (2007). Foreign direct Investment and Economic Growth: The Role of Domestic Financial Sector. Pakistan Institute of Development Economics, WP. No. 18.

Kim, K., \& Bang, H. (2008). The Impact of Foreign Direct Investment on Economic Growth: A case study of Ireland. Korea Institute of International Economic Policy, WP. No. 08-04.

Malik, G. (2008). Foreign Aid and Economic Growth: A cointegration Analysis of the six poorest African counteries. Economic Analysis and Policy, Vol 38 (02).

Miankhel, A. K., Thangavelu, S. M., \& Kalirajan, K. (2009). Foreign Direct Investment, Exports, and Economic Growth in South Asia and Selected Emerging Counteries: A Multivariate VAR Analysis. Centre for Contemporary Asian Studies Doshisha University, 1-28.

Mosley, P. (1987). Aid-Effectiveness: The Micro-Macro Paradox. IDS Bulletin. Institute of Development Studies, University of Sussex. 22-35.

Mohey-uddin, G. (2005). Impact of foreign aid on economic development in Pakistan. Munich personal REPEC Archive. Available on line at MPRA. No.1211

Ndambendia, H. (2010). Foreign Aid, Foreign Direct Investment and Economic Growth in Sub-Saharan Africa: Evidence from Pooled Mean Group Estimator (PMG). International Journal of Economic and Finance, Vol 02 (03).

Nyoni, T. (1997). Foreign Aid and Economic Performance in Tanzania. African Economic Research Consortium. No. 02-08.

Pesaran, M. H., \& Shin, Y. (1995). Long-run Structural Modeling. Department of Applied Economics, University of Cambridge. DAE WP. No. 9419.

Pesaran, M. H., \& Pesaran. B. (1997). Working with Microfit 4.0: An Interactive Approach. Oxford: Oxford University Press.

Pesaran, M. H., Shin. Y., \& Richard J. S. (1999). Bounds Testing Approaches to the Analysis of Long Run Relationships. February (Working Paper). 
Radelet, S. (2006). A Primer on Foreign Aid. Center for Global Development, Working (Washington: Center for Global Development), WP. No. 92

Wang, J. Y., \& M. Blomstrom. (1992). Foreign Investment and Technology Transfer: A Simple Model. European Economic Review. (36), 137-155.

Whitaker. T. (2006). Impact of Foreign Aid on Economic Growth. Department of Economics. Mcnulty College of Liberal Arts.

Zhang, K. (2006). foreign Direct Investment and Economic Growth in China: A Panel Data study for 1992-2004. Conference of WTO, China and Asian Economies, University of International Business and Economics, Biejing, China.

\section{Notes}

Note 1. International Monetary Fund (IMF), World Bank (WB) and United Nation (UN).

Note 2. Due to low incomes, savings and investment remain low.

Note 3. Aid inflow is classified into three broad categories, firstly, official development assistance (ODA) which comprise of largest share of aid and given to middle and low income countries. Secondly, donated by countries of high per capita income to countries which have been formerly a part of Soviet Union. Thirdly, voluntary aid given by non government organizations and charity foundations (Radelet, 2006).

Note 4. Among them include Indonesia, Ghana, Vietnam and Uganda.

Note 5. Bandow (1985) states that takes its roots in the history from Marshall Plan for reconstruction and rehabilitation; it was built to accomplish the resource requirements of Western European economies

Note 6. Official Development Assistance and Foreign Aid are treated as synonyms here.

Note 7. Project as well as non project aid.

Note 8. Included sample form the regions of Africa, Latin America, Asia and Caribbean Countries

Note 9. Czech Republic, Estonia, Hungary, Latvia, Lithuania.

Note 10. Pakistan nuclear policy caused this decline in receiving aid by US.

Note 11. Emerging economies include India, Pakistan, Chile, Malaysia, Mexico and ThailandNote 12. Eviews 5.0

Note 12. Eviews 5.0

Note 13.It is an updated and modified form of Dicky Fuller test.

Note 14. ARDL methodology is introduced by Pesaran and Shin (1996); Pesaran and Pesaran (1997); Pesaran and Smith (1997).

Table 1. Unit Root Test Results

\begin{tabular}{|l|c|l|l|}
\hline Variables & ADF at Level & ADF at First Difference & Decision \\
\hline L(RY) & -0.6997 & $-3.5777^{*}$ & $\mathrm{I}(1)$ \\
\hline L(FDI) & -0.1459 & $-4.5661^{*}$ & $\mathrm{I}(1)$ \\
\hline $\mathrm{L}(\mathrm{FA})$ & $0.4277^{*}$ & $-4.0286^{*}$ & $\mathrm{I}(1)$ \\
\hline LAB & $2.1628^{*}$ & $-2.9159^{*}$ & $\mathrm{I}(0)$ \\
\hline SI & 0.12272 & -3.7497 & $\mathrm{I}(1)$ \\
\hline
\end{tabular}

Note: Null hypothesis of testing unit root states that series is non stationary or contains a unit root. *shows significance at $5 \%$ level of significance.

Table 2. Bound Cointegration Test

\begin{tabular}{|l|c|}
\hline F-Statistics & Probability \\
\hline $10(4.01)$ & 0.00001 \\
\hline
\end{tabular}

Note: values in small brackets are the critical values which are used for bound cointegration test, taken from Pesaran, et al. (2002). Null hypothesis is existence of no cointegration, which is rejected if the calculated value of F-stat is higher than critical value. This estimation considers unrestricted intercept, no trend and number of regressors equal to 3. 
Table 3. Short Run and Long Run Coefficients

\begin{tabular}{|c|c|c|c|}
\hline Variables & Coefficients & \multicolumn{2}{|l|}{ Short run Diagnostic Tests } \\
\hline $\mathbf{C}$ & -0.09 & \multirow{10}{*}{$\begin{array}{l}\mathrm{R}_{\text {adj }}^{2} \\
\text { Serial Correlation LM Test } \\
\text { Heteroscedisticity Test } \\
\text { Ramsey Reset Test } \\
\text { Jarque-Bera Test } \\
\text { DW stat } \\
\text { F- Stat } \\
\text { S.E of Regression }\end{array}$} & \multirow{10}{*}{$\begin{array}{l}0.67 \\
1.4768(0.1193) \\
2.3356(0.0413) \\
1.3876(0.1988) \\
1.5677(0.3675) \\
2.06 \\
10.15 \\
0.02\end{array}$} \\
\hline D(LFDI) & $-0.34 * *$ & & \\
\hline D(FA) & $0.15^{* * *}$ & & \\
\hline D(LSI) & $0.005^{*}$ & & \\
\hline D(LAB) & -0.256 & & \\
\hline LRY(-1) & -0.20 & & \\
\hline LFDI(-1) & $-0.15 * * *$ & & \\
\hline L(FA(-1)) & $0.07 * * *$ & & \\
\hline $\mathbf{L A B}(-1)$ & 0.568 & & \\
\hline LSI(-1) & $0.006^{*}$ & & \\
\hline
\end{tabular}

Note: *significance at $1 \%$ level, ${ }^{* *}$ significance at $5 \%$ level. $* * *$ significance at $10 \%$ level.
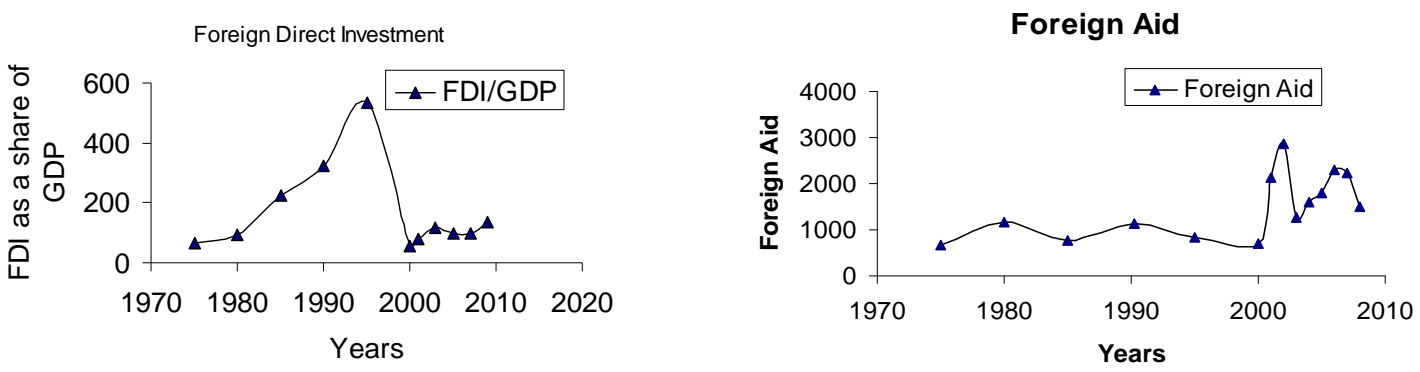

Source: Pakistan Economic Survey, Various issues, and world development indicators.

Figure 1. Statistics Showing Trends of FDI and ODA in Pakistan
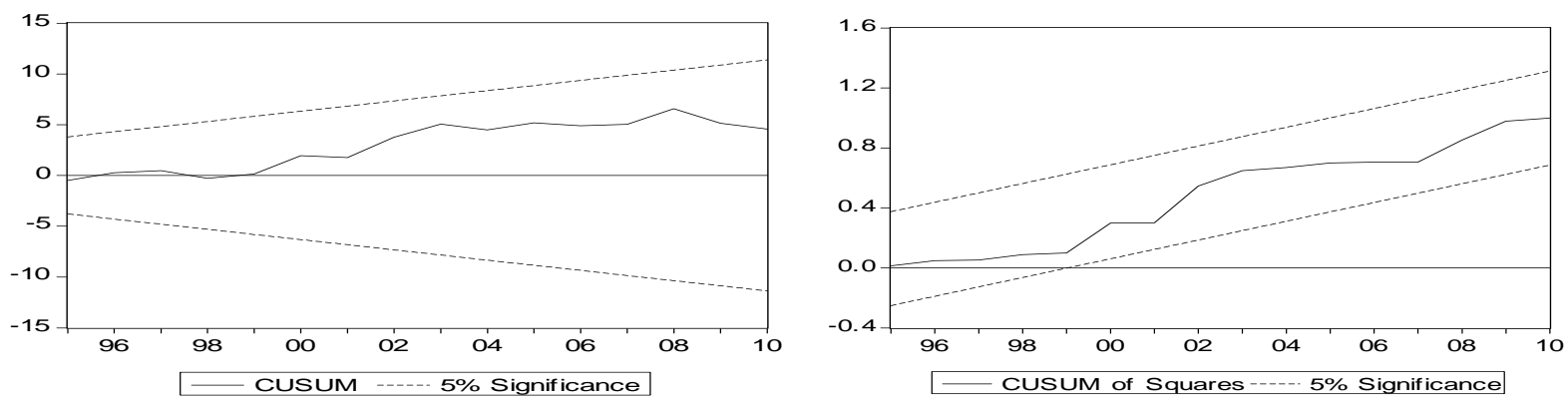

Figure 2. Graphs of CUSUM and CUSMSQ for Stability of Parameters 